\title{
ROLE OF NON-GOVERNMENTAL HUMANITARIAN ORGANIZATIONS IN TIME OF INTERNAL ARMED CONFLICT CASE STUDY AFGHANISTAN
}

\author{
P.L.S Dias* \\ Department of International Relations, University of Colombo, Sri Lanka
}

\begin{abstract}
Non-governmental humanitarian organizations provide humanitarian assistance to armed conflicts and disasters. Different type of non-governmental humanitarian organizations operates in locally and internationally such as local non-governmental humanitarian organizations and international non-governmental humanitarian organizations. These organizations are responsible in providing humanitarian aid according to the humanitarian principles. This research mainly focus on neutrality principle of non-governmental humanitarian organizations in times of internal armed conflict of Afghanistan.
\end{abstract}

The objectives of the research are to identify vital role of non-governmental humanitarian organizations in internal armed conflict of Afghanistan and effectiveness of NGOs. Methodology

consist of secondary data obtained from secondary sources, published materials such as newspapers, reports, books journal articles and annual reports etc Qualitative data taken from opinions, ideas, stories and case histories. These can be obtained from both primary and secondary data. This research mainly based on qualitative study.

It can be concluded that non-governmental organizations vital role based on neutrality principle in Afghanistan internal armed conflict .But there arguments that the neutrality principle can be changed according to complex humanitarian strategies of current global order.

Keyword: Non-Governmental Humanitarian Organizations, Internal Armed Conflict, Neutrality

\section{Introduction}

\section{Background}

Afghanistan located between several countries of different geographical regions such as Middle East, Central Asia and South Asia. Due to its geographical location, Afghanistan is a battleground for multiple wars which was strategically planned by larger external powers since long time. In addition multiple struggles which have gained support from the different external forces occurred in Afghanistan Because of fragmented and polarized nature of Afghan society.Wars in Afghanistan included many civil wars over three decades such as since 1978 to 1992 to overthrow Marxist Government, 1990 -2004 Civil war and after 2004 insurgencies. Nigel Nicholds (1994).

Each time non-government humanitarian organizations have appeared to provide humanitarian aid which consist material or logical assistance to save lives, relieve suffering and uphold human dignity. When government services and control have broken down non-government organizations provide educational, humanitarian, helping to develop dialog among belligerents and advocacy services. The role of non-government humanitarian organizations in time of internal armed conflict in Afghanistan has not been well documented. Annyssa Bellal et al.(2011) 


\section{P.L.S Dias / Role Of Non-Governmental Humanitarian Organizations....}

There are different type of non-governmental humanitarian organizations (NGO) involved in Afghanistan such as foreign non-governmental organizations, Afghanistan non-governmental organisations,non-governmental organizations focusing on women and child. ${ }^{1}$ Main principle factor which contribute to not documented nongovernment organizations role is number of non-governmental organizations are high in Afghanistan. Also lack of centralize sources of information, complexities of the different type of resources flow in the system and in some cases deliberate secrecy of non-governmental organization are some reasons for not documented information.NGOs have taken large relief operations since 1979 in Afghanistan. This case study focus on vital role of NGO involvement in humanitarian assistance in internal armed conflict of Afghanistan and the way that neutrality principle achieved.

Non government humanitarian organizations are expected to provide humanitarian assistance based on humanitarian principles which are grounded in International Humanitarian law humanity, neutrality, impartiality, operational and independence are main humanitarian principles and this research focus on neutrality principle which NGOs must not take sides in hostilities or engage in controversies of a political, racial, religious or ideological nature. ${ }^{2}$

Also this case study is not intended to be exhaustive study of the role of NGOs in the relief operations in Afghanistan due to lack of data sources, not possible interview due to Afghan internal conflict situation, lack of funding for research and lack of institutional activates undertaken within more than three to four years previously many organizations involved in the provision of humanitarian and relief operations. Therefore conducting exhaustive studies are difficult and time consuming. Humanitarian assistance and relative assistance which have been underway several years. Therefore exhaustive studies may simply not possible. These studies are not provided any assessment related to the effectiveness of assistance provided by NGOs. Such assessment would require much more detailed investigation such as all the NGOs involved or at least a representative sample, seeking the views of a sample of die recipients and the assistance provided by them.

In 1978 Socialist agenda was implemented in Afghanistan and the President was Nor Mohammad Taraki. The groups were made by Mujahedeen opposition forces and began attacks aimed at overthrowing the Marxist Leninist government. The Soviet Union supported ruling party as per the request support made by them. At that time US began to support opposition groups to weaken the Soviet Union as a Cold War strategy. This conflict was official ended in year 1989.At that time Soviet forces withdraw from the country. Millions of people dead and internally displaced and country's population fled in to neighboring countries such as Pakistan and Iran. After the communist government had collapsed in 1992 again fell into civil war due to many groups refused to accept new government in Afghanistan. There was no time to reform educational judiciary systems after the Soviet War. Also the country descended into lawlessness. In this time period, different areas were controlled by different armed groups. These armed groups were supported by governments and some groups in external countries such as Saudi Arabia, Iran and Pakistan etc.

A militia group, Taliban began to emerge as a political and religious force in the early 1990.The Taliban groups were able to weakened incumbent government in the year 1996. Then they take over Kabul and established the Islamic Emirate of Afghanistan.

Tailiban became tarnished due to their strict rules especially for women. In December 2001 Taliban government collapsed in Afghanistan Interim government was established in the year 2004, the President was Hamid Karazi. Other external forces of governments such as US, UK, Italy and France joined to fight against insurgency attacks

1 https://afghanistan-analyst.org/ngos/ accessed in $4^{\text {th }}$ of September 2018

2 http://gsdrc.org/topic-guides/international-legal-frameworks-for-humanitarian-ction/concepts/humanitarianprinciples-and-humanitarian-assistance/ accessed in $4^{\text {th }}$ of September 2018 
in Afghanistan. The first presidential elections were held in 2004 an Karzai won the majority of votes albeit with low audience due to fears of electoral violence However since year 2006 insurgency attacks had been increased in Afghanistan and lot of people were killed At the end of 2010 Obama administration had been start to withdraws US troops from Afghanistan. After that Afghan security forces has controlled security matters which were extremely difficult due to large number of suicide bomb attacks.

Afghanistan had been received millions of money to rebuild the nation .But still struggling on this matter. Life expectancy is 44 years compare to the other low income countries. Also highly corruption remain in most of the sectors of the society. After more than three decades of civil war in Afghanistan, the stance of civil society development is shifting slightly over time period.

\section{Statement of the Problem}

Non-governmental Organizations humanitarian role during the internal armed conflict is always problematic to interest parties. Their main role should be provide humanitarian assistance to humanity and military. Thus, the role of non-governmental organization to be evaluated up to what extent their role would be constraint as neutral in Afghanistan.

\section{Objectives of the Research}

- To identify the vital role of nongovernmental organizations in time of armed conflict.

- To evaluate effectiveness of non-governmental humanitarian organizations in internal armed conflict

- To analyses situation of the non-governmental humanitarian organizations in internal armed conflict of Afghanistan.

\section{Hypothesis}

Neutrality of non-governmental organizations is the important factor to play a vital role in internal armed conflict to support victims of the conflict as humanitarian basis.

\section{Research Questions}

- Whether the non-governmental humanitarian organizations achieved their vital role in internal armed conflict?

- Whether non-governmental humanitarian organization able to provide effective humanitarian assistance in the conflict areas?

- What would be the situation of non-governmental humanitarian organizations in Afghanistan?

\section{Theoretical Framework}

Humanitarian principles: humanity, neutrality, impartiality and independence. These principles provide the foundations for humanitarian action. They are central to establishing and maintaining access to affected people, whether in a natural disaster or a complex emergency, such as armed conflict. Promoting and ensuring compliance 


\section{P.L.S Dias / Role Of Non-Governmental Humanitarian Organizations....}

with the principles are essential element factor. Neutrality principle which govern humanitarian response for specific type of humanitarian agencies such as UN agencies, the Red Cross, Red Crescent Movements and NGOs. ${ }^{3}$

These principles, derived from international humanitarian law, have been taken up by the United Nations in General Assembly Resolutions 46/182 (1991) (humanity neutrality and impartiality endorsed ) and 58/114(2004)(independence endorsed). Their global recognition and relevance is furthermore underscored by the Code of Conduct (1994) for the International Red Cross and Red Crescent Movement. Non-Governmental Organizations provide disaster relief, the core humanitarian standard on quality and accountability and effective humanitarian coordination. ${ }^{5}$

These fundamental principles of the International Red Cross and Red Crescent Movement proclaimed in Vienna in 1965 by the 20th International Conference of the Red Cross and Red Crescent Movement ${ }^{6}$. Neutrality means; Humanitarian actors must not take sides in hostilities or engage in controversies of a political, racial, religious or ideological nature ${ }^{7}$

\section{Methodology}

Methodology of this study involves qualitative study. Most of the data can be get it from secondary sources. Qualitative Study involves international reputed books, journal articles, published material, annual reports, newspapers and existing research studies. Also qualitative data from opinions, perceptiveness, ideas, stories, recollections and case histories. These data can be obtained from both primary and secondary sources.

These qualitative data has been collected into some form of explanation of research objectives that this research is investigating Also it provide insights into the problem. Theories from above collected data sources have been taken into prove research questions and research objectives.

\section{Non-governmental humanitarian organizations vital role in internal armed conflict of Afghanistan}

\section{Non-Governmental Humanitarian Organizations in Afghanistan}

Non-governmental organizations operate independently from any form of the government and activate locally and internationally. These organizations provide emergency aid and humanitarian assistance. Experienced NGOs have expertise, detailed knowledge of specific local areas and capacity to supply right help to conflict areas.

NGOs have played vital role in Afghanistan since Soviet inversion in 1979. Depending on the situation sometimes international NGO's banned from the country. During internal conflicts these organizations focused on providing emergency assistance, distribution of food, medical care and shelter. The Afghan government ratified a law in the year 1990. The law allowed NGOs to operate within the country. Hence NGOs received funding from

\footnotetext{
${ }^{3}$ https://www.icrc.org/eng/resources/documents/red-cross-crescent-movement/fundamental-principlesmovement-1986-10-31.htm accused on 10th of September 2018

${ }^{4}$ http://www.un.org/documents/ga/res/46/a46r182.htm accessed on 6th of September 2018

5 https://www.unocha.org/sites/dms/Documents/OOM-humanitarianprinciples_eng_June12.pdf accessed on $5^{\text {th }}$ of September 2018

${ }^{6} \mathrm{https}: / /$ www.unocha.org/sites/dms/Documents/OOM-humanitarianprinciples_eng June12.pdf accessed on 18th of September 2018 accessed on September 2018

${ }^{7}$ https://www.unocha.org/sites/dms/Documents/OOM-humanitarianprinciples_eng_June12.pdf accessed on 18th of September 2018
} 
international organizations such as UN High Commissioner for Refugees(UNHCR) and World Food program(WFP) etc The number of NGOs increased in Afghanistan this resulted in the formation of multiple NGO coordination bodies such as Afghan NGO coordination body to increase professionalism and responsibility within the community.

The Taliban government limited Afghan women access to humanitarian relief work and restricted proving assistance to females including a ban on education for girls. Some international NGOs were expelled from the country and others withdraw under the Taliban ruling time due to harsh restrictions eg Oxfam protest against Taliban policies toward women (Oxfam 1997) since 2001 shortage of NGOs in Afghanistan, then US military was involved in providing humanitarian assistance to conflict areas. Again number of NGOs increased in Afghanistan within the US led invasion.

Non-government humanitarian organization operating in Afghanistan

- International Organizations

- $\quad$ NGO Coordination bodies

- $\quad$ Foreign NGOs

- Afghan NGOs

- $\quad$ NGO for Women

- $\quad$ NGO for children

According to the information from sources, many NGO workers killed in Afghanistan

The International Committee of the Red Cross is halting work in Afghanistan following an attack on its staff which the aid agency said was despicable. Six workers were killed in an ambush of their convoy by suspected militants. Two others are missing. The Red Cross said they needed to temporarily suspend aid activity to understand what had happened.8

Security of the staff is the main challenge for all NGO workers in Afghanistan. Afghanistan is the most dangerous country for aid agencies. The Aid Workers Security Report 2018 shows that the major attacks against the aid workers have taken place in Afghanistan9 The Afghanistan NGO safety office which is an independent project established to provide information and advice to humanitarian organizations on safety conditions across Afghanistan.10 Many international NGOs pulled out of Afghanistan due to security incidents. NGO argued that the allocation of aid is driven by political goals rather than the needs of the population. The UN has provided humanitarian coordination role in Afghanistan. The United Nations Office for the Coordination of humanitarian Affairs OCHA support humanitarian and military actors through training and advocacy as well as they prepared humanitarian response plan in Afghanistan. This response plan based on different clusters including emergency shelter, food security and agriculture, health, nutrition, child protection, gender based violence, housing land property, mine action and water sanitation. 11

\footnotetext{
${ }^{8}$ https://www.bbc.com/news/world-asia-38912482 accessed on 18th September 2018

${ }^{9}$ https://aidworkersecurity.org/sites/default/files/AWSR\%20Figures\%202018.pdf accessed on $18^{\text {th }}$ September 2018

${ }^{10}$ https://www.afgnso.org/index_files/Page368.html accessed on 7th of September 2018

${ }^{11}$ https://www.humanitarianresponse.info/en/operations/afghanistan accessed on 17th of September 2018
} 


\section{Sources of Funding Non-Governmental Humanitarian Organizations}

NGOs providing humanitarian assistance to Afghans are completely self-finance from private donors and they have been received resources from below mentioned sources

- Private donations,

- Grants from government of the country

- Grants from multilateral agencies

- (UN agencies)

The large number of NGOs involved in the system time to time and the complexity of the funding flows didn't provide detailed published reports pertaining to NGO finances in Afghanistan.

\section{Humanitarian Aid}

Non-governmental humanitarian organizations provide different type of humanitarian assistance to people who live in conflict areas of Afghanistan. The type of aid depends on the emergency environment such as save life of people in conflict area, alleviate suffering and protect human divinity etc

Humanitarian non-government organizations are developed to provide different type of aid as per the humanitarian principle and acceptable laws.

\section{Characteristics of Humanitarian Aid}

Humanitarian aid intended to be governed by humanitarian principles including neutrality

Short-term Assistance

Different type of aid include material, relief services, emergency food aid, reconstruction and rehabilitation

\section{Suggestions to develop Humanitarian Assistance provided by Non-Governmental Humanitarian Organizations}

- Development of humanitarian policies and clear division of responsibilities for the different aspects of humanitarian assistance.

- Identify gaps in humanitarian assistance and address it.

- Advocate the effective application of humanitarian aid.

- Develop a common ethical frame work for humanitarian activities.

- $\quad$ Solve disputes with humanitarian agencies and humanitarian work.

- Collaboration work between humanitarian work and development activities.

- Humanitarian agencies must work together to provide better coordinated, well-resourced humanitarian assistance.

- Develop research initiative for humanitarian aid development activities. 


\section{The Role of Humanitarian Aid provided by Non-Government Humanitarian Organizations}

The role of humanitarian aid which was provided by non-governmental humanitarian organizations depends on the conflict situation. Sometimes state parties unable to deliver aid to the conflict area. Then humanitarian nongovernmental organizations will be able to provide required aid without considering parties to the conflict.

Aid strategy will have different objectives to carry out relevant task. One objective is to prevent disastrous consequences such as assist the affected population group directly or to prevent the deterioration of healthcare, agriculture or other local system and the other objective is to prevent the growth of dependence on outside assistance. Humanitarian nongovernmental organization take into account people need for assistance and protection combines short and medium term strategies and seeks to prevent the worst human sequences of armed conflict such as to save lives, relieve suffering, improve health, maintain health care systems, place the victims economy back and restore people dignity. When providing aid to the victims, NGO s consider the level of violence and the effect of humanitarian aid on violence in contact.

\section{Objective of Humanitarian Aid}

Main objectives of humanitarian aid depend on the conflict environment such as reduce violence and save lives, relive and prevent suffering by providing treatment for the wound, food suppliers sanitation, hunger thirst disease elevation and reduce the violation of international human rights law Aforementioned humanitarian action guided by humanitarian principles such as humanity, impartiality, neutrality and independence.

The aid can have effect on the duration of armed conflict. Sometimes it may drag the conflict for a longer period. Also role of aid can be substitute for political action to resolve the conflict eg seeking help to caught victim in a trap and help to lower the violence such as negotiations with conflict parties aimed at a bringing about cessation of hostilities.

\section{Internal Armed Conflict}

Armed conflicts which are non-international in nature, occur between a state (Government forces) and nongovernmental armed groups within the borders of states. But it does not extend the territory of two or more states.

Two main conditions must meet to consider armed conflict as non-international armed conflict

- They must reach a minimum level of intensity and duration

- Parties involved must show a minimum of organization.

Non international armed conflict include more destructive nature for human beings such as civilian attacks, the destruction of civilian property, looting, forced displacement ,the destruction of infrastructure vital to civilian populations, sexual violence, torture and indiscriminate attacks. All are common to non-international armed conflicts throughout the world.

Article 3 of the Geneva Conventions of 1949 for non-international armed conflicts 
Article $3{ }^{12}$ In the case of armed conflict not of an international character occurring in the territory of one of the High Contracting Parties, each Party to the conflict shall be bound to apply, as a minimum, the following provisions:

(1) Persons taking no active part in the hostilities, including members of armed forces who have laid down their arms and those placed ' hors de combat ' by sickness, wounds, detention, or any other cause, shall in all circumstances be treated humanely, without any adverse distinction founded on race, colour, religion or faith, sex, birth or wealth, or any other similar criteria.

To this end, the following acts are and shall remain prohibited at any time and in any place whatsoever with respect to the above-mentioned persons: (a) violence to life and person, in particular murder of all kinds, mutilation, cruel treatment and torture; (b) taking of hostages; (c) outrages upon personal dignity, in particular humiliating and degrading treatment; (d) the passing of sentences and the carrying out of executions without previous judgment pronounced by a regularly constituted court, affording all the judicial guarantees which are recognized as indispensable by civilized peoples.

(2) The wounded and sick shall be collected and cared for. An impartial humanitarian body, such as the International Committee of the Red Cross, may offer its services to the Parties to the conflict. The Parties to the conflict should further endeavor to bring into force, by means of special agreements, all or part of the other provisions of the present Convention. The application of the preceding provisions shall not affect the legal status of the Parties to the conflict.

\section{Neutrality principle for non-government humanitarian role in internal armed conflict of Afghanistan}

Neutrality principle should be analyzed within the context of this case study.

Neutrality is one of the pragmatic tool which provide humanitarian assistance effective way. It is important to secure people in need of protection and assistance in politically charged environments. Some people argue that neutrality which is an operating principle threat for crisis like Afghanistan. But some believe that it is essential for humanitarian action. Also there are different arguments pertaining to neutrality including it is impractical, unrealistic condition and it cost to save lives. Traditional humanitarian principles such as neutrality are demoralized within complex humanitarian strategies and the rise of new global order. ${ }^{13}$ This research argues that neutrality is always make sense as neutral.

It is hard to define neutrality principle all non-governments humanitarian organizations in Afghanistan since 1979 due to increased number of organizations and lack of information within time period. Neutrality as a guiding principle for humanitarian action within the international humanitarian law was considered in the Afghanistan internal armed conflict According to secondary sources sometimes neutrality principle was disallowed by the most of actors in Afghanistan latest conflict due to several factors such as some rejected western aid. Neutrality principle cannot be assessed for each non-government humanitarian organization in Afghanistan. Because the number of NGOs are high .Therefore example has been taken from the International Committee of the Red Cross and Red Crescent Society

12 https://www.cambridge.org/core/books/the-concept-of-non-international-armed-conflict-in-international-humanitarianlaw/article-3-common-to-the-four-geneva-conventions-of-1949-and-the-threshold-of-non-international-armed-conflict-ininternational-humanitarian-law/00F71F8DB6EC99DB2B8A08ACFF2D76B8 accessed on 18t of September 2018

13 https://www.globalpolicy.org/component/content/article/176/31283.html accessed on 20th of September 2018 
Non-government humanitarian organizations main role is assisting victims regardless of their nature (who they are and what is their side) Failure in providing government aid to conflict areas NGOs involve in this matter. The International Committee of Red Cross (ICRC) teams faced difficulties when they reach conflict affected areas to provide assistance largely due to extreme polarization (War on Terror) and the insurgency against the Western backed government.

One of the ICRC member, water engineer, Ricardo Munguia murdered in year 2003 showed that the ICRC could be perceived as neutral in highly polarized context. Sometimes the instrumentalization of aid tarnished the image of humanitarian assistance provided by NGOs such as aid as tool to win the hearts of minds of Afghan population. Western aid organizations have taken neutrality as a guiding principle of their humanitarian action and distribute their aid depending on the objectives of the legitimate side. Sometimes different articles argued that the neutral approach was impossible for conflicts and the integrated military political and humanitarian approach was involved in future.

The major challenged faced by the ICRC and other non-governmental humanitarian organizations to maintain its neutral role in assisting victims on all sides of the conflict. Some cases reported that aid workers captured in hostage release operations in Khabul, therefore neutrality concept was not effective in the conflict such as in year 2007 Korean missionaries captured in Khabul. But some reported cases neutrality action was successful such as ICRC had obtained safe channel for Polio vaccination teams behalf of the Ministry of Health and the World Health Organization, The ICRC negotiated a ceasefire between the armed opposition of the Afghanistan and US forces. The ICRC medical personal treated cholera victims in Kandhar district . They have an important humanitarian impact in reducing the suffering of injured civilians, police and insurgents alike. The neutral stance was rejected by both sides due to war on terror/war on Islam.

West raised a question whether neutrality was still appropriate means to gain access to people in need. ICRC and other non-government humanitarian organizations travelled freely in all conflict affected of Afghanistan, humanitarian dialogue and developing humanitarian assistance. Also NGOs involved in situations of extreme need and suffering in armed conflict with the assurance that their personal, their property and their daily activities should not be made the object of the attack.

International Committee of the Red Cross (ICRC), to act in situations of extreme human need and suffering, particularly in circumstances of armed conflict, with the assurance that their personnel, their property, and their activities will not be made the object of attack. It is a concept that is at the core of all humanitarian relief work, especially during war, when the cooperation of the belligerent parties is essential to the relief of suffering and privation. It rests upon two pillars: neutrality, which is the assurance given by humanitarian agencies that their efforts are not in military support of either side International Committee of the Red Cross (ICRC), to act in situations of extreme human need and suffering, particularly in circumstances of armed conflict, with the assurance that their personnel, their property, and their activities will not be made the object of attack. It is a concept that is at the core of all humanitarian relief work, especially during war, when the cooperation of the belligerent parties is essential to the relief of suffering and privation. It rests upon two pillars: neutrality, which is the assurance given by humanitarian agencies that their efforts are not in military support of either side.'

There are so many arguments pertaining to the neutrality principle in Afghanistan internal armed conflict. Neutrality is essential to secure people in politically charged environment. Sometimes non-governmental humanitarian organizations in Afghanistan must stress its neutrality by indiscriminately providing aid to victims of the war due to fragmented environment.

The role of non government humanitarian organizations cannot be neutral due to poor security in violent conflict areas in Afghanistan It was identified a series of attacks on UN and NGO aid workers in Afghanistan UN and other aid groups withdraw from these regions. NGO often struggle to remain effective amid military, political and social dynamics. Specially NGO face real problems when operating in violent environments So many thinkers 


\section{P.L.S Dias / Role Of Non-Governmental Humanitarian Organizations....}

questioned about the effectiveness of their efforts within such environment. Indeed aid operations in Afghanistan have been accused. Several international no government humanitarian agencies' provided relief assistance to the most vulnerable conflict and disaster populations based on neutrality principle including emergency shelter, food assistance, medical care, protection services and health services

Some NGO such as Oxfam, Care, Save the Children mentioned that militarization of aid can be seen in Afghanistan and there was a public campaign against it.

\section{Effective humanitarian Assistance provided by non-governmental humanitarian organizations in Afghanistan}

Effective humanitarian assistance means the ability to offer best possible assistance and protection to people in conflicts. Non-government humanitarian organizations need to provide assistance in relevant manner which could be accountable for populations. There are different understandings of humanitarian effectiveness such as effectiveness of the act itself, longer term consequences etc.

Long term consequences means latter these consequences are interested to provide humanitarian action such as human rights, justice, development and peace building. Hence these objectives transform the society in which they operate. Indeed parties to the conflict do monitor how humanitarian organization work example Afghanistan rebel group used telecommunication technology to monitor funding sources for NGOs. Because sometimes NGOs received bulk of money from belligerent states as lacking neutrality. Therefore transparency is important factor in this regard. Maintain a dialogue between all parties are required for humanitarian effectiveness.

\section{Impact of non-governmental organizations in Afghanistan internal Armed Conflict}

Over several decades NGOs have worked in Afghanistan to provide humanitarian assistance for agriculture, health, education, water supply and sanitation. Therefore challenges faced by NGOs while working under different regimes and varying levels of insecurity. NGOs must remain neutral whilst working with Afghan government, and other parties to conflicts. Despite dangers in Afghanistan in 1980 and 1990s, NGOs worked safely in Afghanistan. Sometimes NGOs and UN targeted by attacks and risk to aid personnel showed in while continuing programs in some areas.

\section{Conclusion}

This research mainly focuses on the role of non-governmental humanitarian organizations in time of internal armed conflict of Afghanistan. Non-governmental organizations operate independently from any form of the government .These organizations played a major role of the humanitarian aid system and vary widely in their performance, professionalism, sense of responsibility. According to humanitarian principles, neutrality principle analyzed with regard to the distribution of aid to victims in Afghanistan. Most of the difficult time in Afghan internal conflict, NGOs provide humanitarian assistance as per the neutrality principle which was included in the Code of Conduct for ICRS and Red Crescent Movements. There were several arguments for neutrality principle which can be changed according to the complex humanitarian strategies in current global order. The neutrality of humanitarian organizations is the important factor to play a vital role in internal armed conflict to support victims of the conflict on humanitarian basis. But in certain cases it was observed that non-governmental organizations humanitarian role during the internal armed conflict is always problematic to interest parties such as instrumentalization of aid etc. Many aid workers killed in Afghanistan which is a dangerous country for NGOs. But NGOs always provided humanitarian assistance with the NGO coordination bodies and with the guidance of UN agencies.

Effective humanitarian assistance provided for long term Afghan internal armed conflict. But the effectiveness can be analyzed up to certain extent due to non-availability of data 
The main rationale of this case study is analyzed neutrality principle, vital role and effectiveness of nongovernment humanitarian organization in Afghanistan based on collected information.

\section{Reference}

Richard Barajas, Rachel Howard, Andrew Miner, Karina Siver,2006,'Nation Building in Afghanistan: A Role for NGOs', Workshop in Public Affairs

Nigel Nicholds,John Borton,1994,' The Changing Role of NGOs in the Provision of Relief and Rehabilitation Assistance

Afghanistan Recruitment to Tailban,2017

Jonathan Goodhand, 2002,'Aiding Violence or Building Peace? The role of international aid in Afghanistan', Third World Quartely,vol 23,no 5,pp 837-859

Jonathan Godhand,2013,'Contested Boundaries:NGOs and Civil Military Relations in Afghanistan', Central Asian Survey, vol 32

International Rescue Committee, 2014, what next for Afghanistan?

David M Mitchell,2014,' NGO Presence and Activity in Afghanistan, 2000-2014: A Provincial-Level Dataset', International Journey of Security and Development,

Robert Lidner,2010, 'Non-Governmental Aid Organizations in Afghanistan between impartiality and Counterinsurgency, Journal of Foreign Security and Peace,pp223-227

Annual Report on Protection of Civilians in Armed Conflict ,2008

Annyssa Bellal, Gilles Giacca, Stuart Casey-Maslen,2011,'International Law and Armed Non State Actors in Afghanistan', International Review of the Red Cross,vol 83

Vincent Bernad,2011,'Conflcit in Afghanistan II',International Review of the Red Cross,vo193

Kenneth Anderson,2004,' Humanitarian Inviolability in Crisis: The Meaning of Impartiality and Neutrality for U.N. and NGO Agencies Following the 2003-2004 Afghanistan and Iraq Conflicts', Harvard Human Rights Journal, vol 17

Alastair J. McKechnie1,2002, 'Humanitarian Assistance, Reconstruction \& Development in Afghanistan: A Practitioner's View'.

World Report on How important is neutrality to humanitarian agencies?

Lara Olson,2006,'Fighting for Humanitarian Space :NGO in Afghanistan', Journal of Military and Strategic Studies, vol 9

Dyan Brown,2009,'The effectiveness of NGO within Civil Society'.

https://www.cambridge.org/core/books/the-concept-of-non-international-armed-conflict-in-internationalhumanitarian-law/article-3-common-to-the-four-geneva-conventions-of-1949-and-the-threshold-of-noninternational-armed-conflict-in-international-humanitarian-law/00F71F8DB6EC99DB2B8A08ACFF2D76B8 accessed on 10th of September 2018

https://www.cambridge.org/core/journals/international-review-of-the-red-cross/issue/conflict-in-afghanistan-ii accessed on 10th of September 2018

https://odihpn.org/magazine/does-it-still-make-sense-to-be-neutral/ accessed on 10th of September 2018

https://www.icrc.org/en/who-we-are/mandate?_accessed on 12th of September 2018

https://www1.essex.ac.uk/rightsinacutecrisis/report/morris.htm\#intro accessed on 12th of September 2018

https://www.globalpolicy.org/home.html accessed on 12th of September 2018

https://www.globalpolicy.org/ngos/role-of-ngos-in-the-international-arena/49066-afghanistan-aid-groups-saynato-threatens-their-neutrality.html

accessed on 16th of September 2018

https://www.peaceinsight.org/about/

accessed on 16th of September 2018

https://reliefweb.int/countries 
P.L.S Dias / Role Of Non-Governmental Humanitarian Organizations....

accessed on 17th of September 2018

https://www.foreignaffairs.com/issues/2018/97/5

accessed on 19th of September 2018

https://www.afgnso.org/index.html

accessed on 10th of September 2018

https://odihpn.org/magazine/does-it-still-make-sense-to-be-neutral/

accessed on 10th of September 2018

https://www.jstor.org/stable/27800644?seq=1\#page_scan_tab_contentsaccessed on 10th of September 2018 